\title{
Position of Syar'iyah Aceh Court Based on the Law of the Republic of Indonesia Number 11 of 2006 Concerning the Government of Aceh
}

\author{
Hadi Iskandar* Romi Asmara Yusrizal Hamdani \\ Law Faculty, University of Malikussaleh Indonesia \\ * E-mail of the corresponding author: hadi.iskandar@unimal.ac.id
}

\begin{abstract}
Before the Presidential Decree of the Republic of Indonesia No. 11 of 2003 concerning the Syar'iyah Court and the Syar'iyah Court of Nanggroe Aceh Darussalam Province, there were 2 (two) views on the establishment of the Syar'iyah Court with regard to Law No. 18 of 2001, First, the Syar'iyah Court is a separate judicial body outside the Religious Court and the High Court of Religion, Second, the Syar'iyah Court is the development of the High Religious Court and the Religious High Court. Which refers to Law No. 7 of 1989, concerning religious courts. But based on Article 1 paragraph (1) and (3) of KEPPRES Number 11 of 2003, the Existing Religious Court in Aceh Province was changed to the Syar'iyah Court and the Religious High Court in Banda Aceh was changed to the Provincial Syar'iyah Court, thus the second view contains the issue of court power when connected with the implementation of Islamic shari'ah as formulated in Aceh Provincial Regulation No. 5 of 2000, about the Implementation of Islamic Shari'ah which also covers the field of muamalah and jinayah. The power of the Religious Court and the High Court of Religious Affairs, namely the fields of Marriage, inheritance, wills, grants, waqaf, zakat, infaq, sahdaqoh, and sharia economy. On the other hand, it develops in Acehnese society that wants the power of the Syar'iyah Court more broadly both in the field of ahwal al-shakhsiyah (family law), muamalah (civil law), and jinayah (criminal law based on Islamic shari'ah'at. This paper will describe the position of the Shari'iyah Court based on Indonesia's positive law.
\end{abstract}

Keywords: Position, Syar'iyah Court, Aceh

DOI: $10.7176 / \mathrm{JLPG} / 118-15$

Publication date: February $28^{\text {th }} 2022$

\section{Introduction}

At the beginning of the independence of the Republic of Indonesia, the existence of the Syar'iyah Court (Religious Court) in Aceh, in addition to being a continuation of the Religious Court in Japanese times, was also based on the wire of the Governor of Sumatra Province dated February 22, 1947 Number 226/3/Djaps which contained an order to establish the Syar'iyah Court in Aceh.

Then strengthened again by the decision of the Workers' Board of the Aceh People's Representative Council Number 35 dated December 3, 1947. After that the Syar'iyah Court in Aceh went well until the issuance of Government Regulation No. 29 of 1957 concerning the Syar'iyah Court in Aceh Province. ${ }^{1}$

Based on the description of the existence of Islamic Justice, especially the Syar'iyah Court in the past in Aceh as outlined above, that the presence of Islamic Sharia Justice conducted by the Syar'iyah Court in Aceh Province today, is not a gift from the central government to the people of Aceh, but rather a "Return of Rights of acehnese people who have been lost". ${ }^{2}$ Therefore, its presence and work in the aceh community as part of the implementation of Islamic Sharia kaffah in Aceh Province is something that people are waiting for in this land of Rencong.

The birth of Law No. 44 of 1999 and Law No. 18 of 2001 and Law No. 11 of 2006 brought great hope for the people of Aceh for the implementation of Islamic shari'ah in Aceh Province, and there is a very interesting and different study, especially regarding the position of the Religious Court in Aceh, whether it is in four judicial environments or is a special judiciary called the Syar'iyah Court in Aceh including the addition of its authority in aceh. completing the field of syar'iyah in Aceh including the addition of its authority in completing the field of jinayah (criminal).

But in reality until now, both legally and socially there has been absolutely no change, except that in Aceh has been born the Islamic Sharia Office and some provisions of Qanun, even though the birth of the law makes the people of Aceh today have a Common Plaftform (common idea) that can increase public trust and make their dignity and dignity thick with the nuances of Islamic Sharia protected.

The existence of the Syar'iyah Court in Aceh was strengthened by the issuance of Presidential Decree of the Republic of Indonesia Number 11 of 2003 on the Change of Religious Courts to the Syar'iyah Court in Aceh

\footnotetext{
${ }^{1}$ Ahmad Gunarya, 2006, Pergumulan Politik \& Hukum Islam, pustaka Pelajar, Semarang, p. 2.

${ }^{2}$ Sofyan M. Saleh, 2003, Syar'iyah Court in Prov. NAD. Mimeo, Paper presented at the Training of Judges of the Syar'iyah Court in Banda Aceh, August 25
} 
Province. The existence and establishment of the Syar'iyah Court located in Nanggroe Aceh Darussalam was established and declared valid on March 4, 2003. Referring to the decision of the President of the Republic of Indonesia Number 11 of 2003, the Syar'iyah Court and the Provincial Syar'iyah Court directly replace the function of the authority of the Religious Court (PA) to the authority of the Syar'iyah Court and the authority of the Religious High Court (PTA) to the Provincial Shari'iyah Court, then since March 4, 2003 all facilities, infrastructure, employees and equipment of the court and the jurisdiction of the Religious Court in Aceh Province belong to the Shari'iyah Court in the Regency / City. in Aceh Province. The Syar'iyah Court is used as an Islamic shari'ah court with absolute authority covering aspects of Islamic Shari'ah, the arrangements stipulated by qanun.

Before the issuance of Presidential Decree No. 11 of 2003 concerning the Syar'iyah Court and the Syar'iyah Court of Nanggroe Aceh Darussalam Province, there were 2 (two) views on the establishment of the Syar'iyah Court with regard to Law No. 18 of 2001, First, the Syar'iyah Court is a separate judicial body outside the Religious Court and the High Religious Court, Secondly, the Syar'iyah Court is the development of the High Religious Court and the Religious High Court that refers to Law No. 7 of 1989, on Religious Justice. But based on Article 1 paragraph (1) and (3) of KEPPRES Number 11 of 2003, the Existing Religious Court in Aceh Province was changed to the Syar'iyah Court and the Religious High Court in Banda Aceh was changed to the Provincial Syar'iyah Court, thus the second view contains the issue of court power when connected with the implementation of Islamic shari'ah as formulated in The Aceh Provincial Regulation No. 4 of 2000, about the Implementation of Islamic Shari'ah which also covers the field of muamalah and jinayah.. ${ }^{1}$ The power of the Religious Court and the High Court of Religious Affairs, namely the fields of Marriage, inheritance, wills, grants, waqaf, zakat, infaq, sahdaqoh, and sharia economy. ${ }^{2}$ On the other hand, it develops in Acehnese society that wants the power of the Syar'iyah Court to be broader both in the field of ahwal al-shakhsiyah (family law), muamalah (civil law), and jinayah (criminal law based on Islamic shari'ah'at)..

Based on the observations made by the author, it is interesting to conduct research in this field with the aim to enrich scientific insights both for the author himself and for others who want to pursue in the field. The problem that will be studied in this paper is about the position of the Aceh Syar'iyah Court based on Indonesia's positive law.

\section{B. RESEARCH METHOD}

This type of research is normative research, meaning that this study is a study that describes, examines, explains and analyzes the issues regarding the position of the Syar'iyah Court in Indonesian positive law, the research method used in this study is a descriptive method of analysis that describes the facts studied, then analyze and evaluate the problems contained in these facts or describe some of the problems contained in the laws and regulations, especially regarding the position of the Syar'iyah Court in the implementation of special autonomy based on Law No. 11 of 2006 concerning the Government of Aceh, which will then be analyzed using the concepts contained in the framework of thinking, with a normative juridical approach9, through the approach of Normative juridical, the author examines the rules of law and rules that apply from the aspect of the rules of constitutional law, especially the rules related to the administration of government in Aceh province as part of the Unitary State of the Republic of Indonesia.

The System of Government of the Unitary State of the Republic of Indonesia in the Constitution of the Republic of Indonesia of 1945 recognizes and respects local government units that are special or special in nature. The travel of the Republic of Indonesia places Aceh as a special and special unit of local government, related to the distinctive character of the history of the struggle of acehnese people who have high resilience and fighting power.

\section{DISCUSSION}

1. State theory of law

The Islamic Shari'ah trial in Aceh Province is carried out by the Syar'iyah Court which is also part of the national legal system, the Sharia Court in several laws and regulations on the implementation of Islamic shari'ah in Aceh since the exit of Law No. 18 of 2011 on Special Autonomy of Aceh Province, First, the provisions on the Syar'iyah Court which are declared as part of the national judicial system. Second, Qanun Number 10 of 2002 concerning the Islamic Shari'ah Justice. The most important substance in this Qanun is about the addition of authority possessed by the Syar'iyah Court which is not only related to Islamic civil matters, but also the issue of mu'amalah and jinayah stipulated in the qanun-qanun shari'ah. Third, presidential decree No. 11 of 2003 concerning the Syar'iyah Court and the Provincial Syar'iyah Court in Aceh Province.

\footnotetext{
${ }^{1}$ Article 5 Paragraph (2) of Aceh Provincial Regulation No. 5 of 2000 concerning the Implementation of Islamic Sharia Includes: (a) Aqidah; (b) Worship; (c) Mu'amalah: (d) Morals; (e) Islamiyah education and da'wah/amarma'ruf nahinmungkar; (f) Baitul Mal; (g) The wording; (hP Shiar Islam; (i) Qadha; (j) Jinayat; (k) Munakahat; (l) Mawaris

${ }^{2}$ Article 48 of Law No. 3 of 2006 on Amendments to Law and No. 7 of 1989 on Religious Justice
} 
Qanun Aceh Province as a regulation for the implementation of the implementation of special autonomy in accordance with the authority given to Aceh Province as a special autonomous region. Therefore, in the implementation of the special autonomy law of the Aceh Provincial Government there is no need to wait for government regulations as guidelines for the implementation of the Aceh Provincial Government. Qanun is mentioned at the level of local regulations as the implementation regulations of local-level laws and regulations are made for the implementation of local governments. Because the Regional Government is as a unit of lowerlevel territorial government that has the right to regulate and take care of some government affairs as its own household affairs. Regional household affairs are sourced in autonomy and maid duties (medebewind). The current system of autonomy is rill or real autonomy, either broad autonomy or special autonomy.

This law focuses on special autonomy for Aceh Province, its implementation is placed in regencies and cities or other names on a provisional basis. This specificity is a valuable opportunity to make adjustments to the structure, arrangement, formation and naming of the government below that is in accordance with the soul and spirit of the nation and state that lives in the noble values of Acehnese society, regulated by local regulation called Qanun. According to this law Qanun Aceh Province is a regional regulation of Aceh Province, which can convey other laws and regulations, and the Supreme Court is authorized to conduct material tests against Qanun. ${ }^{1}$

As Supardan Modeong mentioned, if we look from the point of view of the procedure of making laws and regulations between the Regional Regulation (Perda) and Qanun is the same. Namely the regulations made by the Regional Representative Council together with the governor to regulate the implementation of Regional Government in the framework of Regional autonomy. But viewed from the point of power of regulating Qanun is different from regulating perda. Because it is caused that Qanun is not subject to Government Regulation (PP) and Presidential Decree (Keppres), while the Regional Regulation is subject to these two things. Therefore, just as other laws and regulations have binding and enforceable powers, so is the case with Qanun. ${ }^{2}$

Prevention or cancellation that can be done by the central government on two things, namely 1). Preventive and repressive surveillance. Prevention is the prevention of the nature of preventing so that local governments do not take policies that are in agreement with the regulation, and 2). Supervision that is cancellation / removal is the supervision of revocation or restrictions on policies that have been set by the local government. ${ }^{3}$

Like the construction of Qanun Jinayah by the Government of Aceh which has been passed by the Aceh People's Representative Council (DPRA), now there are pros and cons to the ratification of qanun jinayah which regulates the material and formal law, in it regulates the law of razam to death for adulterers. For those who agree to be enforced razam law on the grounds that razam law is in accordance with Islamic sharia, while for those who are counter and supported by the local government consider razam law violates human rights.

Until now the Qanun jinayah was not signed by Gubenur and will be discussed again can be set in the Blood sheet. When guided by 79 paragraph (2) of Law No. 12 of 2012, the establishment of laws and regulations. After within a period of no later than 30 (thirty) days the draft regional regulation after mutual approval is not signed by the Governor or Regent, the regional regulation is valid to become a Regional Regulation and must be promulgated. So the function of the local government as a representative of the central government is very important to unite the community and the Aceh Government law is not completely free to make qanun and the function of qanun should not conflict with higher laws and regulations.

Because Qanun is mentioned as a local regulation that has a special "plus" value applies in Aceh Province which is different from other regional regulations in Indonesia, the power and authority given to form Qanun based on Law No. 44 of 1999 and Law No. 11 of 2006 concerning the Government of Aceh which states, Qanun Aceh is a law similar to provincial regulations governing the implementation of government and life. The people of Aceh, then formed some Qanun about the implementation of Islamic Shari'ah in Aceh Province as follows:

1. Qanun Number 10 of 2002 on Islamic Sharia Justice

2. Qanun Number 11 of 2002 on the Implementation of Islamic Shari'ah in the Field of Aqidah, Worship of Islamic Shari'ah funds.

3. Qanun Number 12 of 2003 on Khamar Drinks and the like

4. Qanun Number 13 of 2003 on Maisir (Gamblers)

5. Qanun Number 14 of 2003 on Khalawat (Pervert)

Thus, the law is higher in position than the Provincial Regulation, Regency Perda or City Regulation. Therefore, in accordance with the hierarchical principle of the laws and regulations, the lower regulations should not conflict with the higher degrees of regulation 37 . However, as a consequence of affirming the principle of separation of executive, legislative and judicial powers in the first amendment of the 1945 Constitution, the legislative products of this area may be contrary to executive products at the central level. For example, if a

\footnotetext{
${ }^{1}$ See General Explanation Clause of Law No. 18 of 2001 on special autonomy.

2 Supardan Modeong,,2003, Teknik Perundang-undangan di Indonesia, Jakarta, p. 69.

${ }^{3}$ Hanif Nurcolis, 1999, Teori dan Praktek Pemerintahan dan Otonomi Daeran, Jakarta, Medeia Press, p. 27.
} 
material of the Provincial Regional Regulation or District / City level Regional Regulation that has been legally established turns out to be contrary to the material of the Minister's Regulation at the central level then the court must determine that the Regional Regulation is applicable throughout the Region.

Ministerial regulations are intended to be generally applicable throughout Indonesia. Therefore, the provisions governing that local regulations must be passed first by the Central Government, in this case by the Minister of Home Affairs, must be declared no longer valid. The Constitution of the Republic of Indonesia of 1945, mandates that the Regional Government be obliged and authorized to regulate and manage government affairs according to the principle of autonomy and assistance duties. Granting broad autonomy to the region with regard to the principles of democracy, equality, justice, privilege, and specificity and regional diversity in the system of the Unitary State of the Republic of Indonesia.

In the religious court environment there is an Islamic Sharia Court in Aceh conducted by the Syar'iyah Court. Islamic Sharia Justice in Aceh. The Syar'iyah Court is a special court in the religious justice environment as long as its authority concerns the authority of the religious judiciary, and is a special court in the general judicial environment as long as its authority concerns the authority of the general judiciary.

Based on the above, the special court can be seen from the object of the case being tried and also based on the authority of the judicial body, when viewed from the object of the case, there are cases that require special expertise in its examination, the field is not all judges can try it because of the limitations of judges in that field such as commercial matters, human rights and taxes. In addition to requiring special skills, there are also courts that require special handling such as children's courts so that children who need criminal acts do not feel that they are being tried so that a family impression must be created for children.

Islamic sharia justice in Aceh conducted by the Syar'iyah Court is a special court when viewed in terms of authority. It is said that the court is special when viewed in terms of the authority it has. It is said to be a special court because the Syar'iyah Court in Aceh Province has 2 (two) authorities at once, namely the authority of the general court and the authority of religious courts conducted by one judicial body.

Islamic Shari'ah in Aceh has been specifically enforced, namely with the release of Law No. 11 of 2006 concerning the Government of Aceh, then juridically islamic sharia becomes a positive law for the nad community, because Islamic sharia has regulated all aspects of community and state life in a kaffah. The logical consequences of the enactment of the Law on Aceh government and Islamic sharia as the legal basis for this NAD community, then all levels of NAD society that are Muslim must be legal to obey and practice Islamic sharia.

This law based on Islamic sharia, because it is already a positive law for Acehnese people who are islamic, if the community commits violations of Islamic sharia or other violations of law, such as committing jinayah (criminal acts), then for Acehnese people who are Muslim will be tortured and tried by the Syar'iyah Court not by the District court anymore, namely the court as the implementer of judicial power in the environment. Religious justice is part of the national judicial system.

With the increasing authority of the Syar'iyah Court to examine and adjudicate cases that were previously the authority of the district court, it will also increase the volume of cases that enter to be examined and tried, so that it will be busy and reliable human resources are needed, both judges and their employees, because so far the Syar'iyah Court has not been accustomed to examining and adjudicating cases such as in state courts. Therefore in the Syar'iya Court it is necessary to add judges and employees, because their duties and authority are doubled from before.

\section{CONCLUSION}

With the enactment of the Aceh Government Law, almost all the Authority of the District Court in terms of examining and adjudicating criminal cases and civil cases will be transferred to the Syar'iyah Court, especially for defendants and seekers of justice who are diverse in Islam. This is in accordance with the provisions in article 128 paragraph (2) of uupa, which reads: "The Syar'iyah Court is a court for everyone who is Muslim and is in Aceh". Even the authority of people who are not Muslim according to the provisions of article 129 paragraph (1) of the UUPA can also be transferred from the district court to the Syar'iyah Court.

\section{BIBLIOGRAPHY}

A. Roihan Rasyid., 1989. Upaya Hukum Terhadap Putusan Peradilan Agama. Jakarta. Pedoman Ilmu Jaya. Ahmad Gunarya, 2006, Pergumulan Politik \& Hukum Islam, pustaka Pelajar, Semarang.

Al Yasa Abubakar., 2006, Hukum Pidana Islam di NAD, Banda Aceh, Dinas Syari'at Islam Provinsi Nanggroe Aceh Darussalam.

Ali Hasyimi, 1983, Kebudayaan Aceh Dalam Sejarah, Jakarta, Beuna.

Areif Muljadi, 2005. Landasan dan Prinsip Hukum Otonomi Daerah dalam Negara Kesatuan RI, Jakarta, Prestasi Pustaka.

Bambang Sunggono.,2005. Metodologi Penelitian Hukum. Jakarta: Raja Grafindo Persada. 
Hanif Nurcolis, 1999, Teori dan Praktek Pemerintahan dan Otonomi Daeran, Jakarta, Medeia Press. Harsono,1992, Hukum Tata Negara Pemerintahan Lokal Dari Masa Ke Masa, Yogjakarta, Liberty.

Sofyan M. Saleh, 2003, Syar'iyah Court in Prov. NAD. Mimeo, Paper presented at the Training of Judges of the Syar'iyah Court in Banda Aceh, August

Supardan Modeong,,2003, Teknik Perundang-undangan di Indonesia, Jakarta. 